\title{
Blockade of anxiolytic-like actions of chlordiazepoxide by naloxone in the elevated plus-maze: Comparisons between Swiss, $\mathrm{C} 57 \mathrm{BL} / 6$, and BALB/c mice
}

\author{
ANDERS ÅGMO \\ University of Tromsø, Tromsø, Norway \\ and \\ CATHERINE BELZUNG, XAVIER DELOIRE, MATHILDE GRASSIN, and SANDRA LEWIS \\ University of Tours, Tours, France
}

\begin{abstract}
The ability of the opiate antagonist naloxone to block the anxiolytic-like effects of chlordiazepoxide in the elevated plus-maze was evaluated in Swiss, $\mathrm{C} 57 \mathrm{BL} / 6$, and $\mathrm{BALB} / \mathrm{c}$ mice. In our version of this procedure, a dose of $5 \mathrm{mg} / \mathrm{kg}$ of chlordiazepoxide was necessary in all three strains to increase the proportion of open-arms entries, the parameter supposed to best represent anxiolytic activity. No significant effect was obtained on closed-arms entries, suggesting that the anxiolytic-like effect observed was not a consequence of locomotor stimulation. However, in the BALB/c mice, there was a nonsignificant tendency for an increase of closed-arms entries. When chlordiazepoxide, $5 \mathrm{mg} / \mathrm{kg}$, was combined with naloxone, $10 \mathrm{mg} / \mathrm{kg}$, the effects of the benzodiazepine were blocked in the Swiss and C57BL 6 strains but not in the BALB/c strain. If anything, naloxone seemed to enhance the actions of chlordiazepoxide in this strain, but this effect failed to reach statistical significance. The antagonism by naloxone of the anxiolytic-like effects of chlordiazepoxide in the Swiss and C57BL/6 strains coincides with previous results obtained in the rat and in the light/dark choice test and the free exploratory paradigm in mice. The lack of antagonism in the BALB/c strain also coincides with previous results from these procedures. It is suggested that the opioid system is not important for the anxiolytic-like actions of benzodiazepines in $\mathrm{BALB} / \mathrm{c}$ mice. This may be due to no or small release of opioids in response to stress in this strain.
\end{abstract}

The opiate antagonist naloxone has been reported to block the anxiolytic-like effects of benzodiazepines and meprobamate in the rat and mouse in several behavioral paradigms ( ̊̊gmo, Galván, Heredia, \& Morales, 1995; Billingsley \& Kubena, 1978; Duka, Cumin, Haefely, \& Herz, 1981; Koob, Strecker, \& Bloom, 1980; Soubrié, Jobert, \& Thiebot, 1980; Tsuda, Suzuki, Misawa, \& Nagase, 1996). One explanation for this could be that naloxone acts as a GABA antagonist. In fact, large doses of naloxone (several hundreds of $\mathrm{mg} / \mathrm{kg}$ ) may produce convulsions, an effect typical of, but not specific to, GABA antagonists (Dingledine, Iversen, \& Breuker, 1978). However, this explanation is unlikely, because the motor incoordination produced by large doses of benzodiazepines and pentobarbital is not blocked by the opiate antagonist

Part of the data in this article was presented at the Second Meeting of the French Neuroscience Society, Lyon, France, May 14-18, 1995. Ann Marie Le Guisquet provided excellent animal care. The figures were produced by Serge Barreau. Correspondence concerning this article should be addressed to A. Agmo, Department of Psychology, University of Tromsø, N-9037 Tromsø, Norway (e-mail: andersa@psyk. uit.no).
( $\AA$ gmo et al., 1995; File, 1982), whereas these effects are readily blocked by the GABA antagonist picrotoxin ( $\AA$ gmo \& Fernández, 1991; Ågmo, Pruneda, Guzmán, \& Gutiérrez, 1991; File, 1982). In addition, the anxiolytic actions of benzodiazepines are not blocked by GABA antagonists, in a procedure identical to that used in some studies with naloxone ( $\AA$ gmo et al., 1991). There are also data showing that naloxone potentiates the actions of GABA agonists on ambulatory activity ( $\AA$ gmo \& Tarasco, 1985), something not compatible with GABA antagonistic properties.

Another possible explanation for naloxone's capacity to block anxiolysis induced by several drugs is that activation of opioid systems is essential for anxiolytic-like drug effects. There is, in fact, evidence showing that benzodiazepines activate endorphins at some brain sites (Duka, Wüster, \& Herz, 1979; Harsing, Yang, \& Costa, 1982; Wüster, Duka, \& Herz, 1980) and that this effect is blocked by naloxone (Duka, Wüster, \& Herz, 1980). It has also been shown that opioid systems are activated by several kinds of stressors in rats and humans (Boone \& McMillen, 1994; Hennig, Laschefski, \& Opper, 1994; Larsen \& Mau, 1994; Schedlowski et al., 1995). In the human, an inverse relationship between the concentration 
of $\beta$-endorphin in cerebrospinal fluid and the subjective experience of stress has been reported (Brady et al., 1991). It has also been shown that plasma $\beta$-endorphin concentration is related to the decrease in anxiety observed after long-distance running (Dienstbier et al., 1981). Moreover, intracerebroventricular infusion of $\beta$-endorphin enhances flunitrazepam binding in the cortex (Gomar, Castillo, del Aguila, Fernández, \& Acuña-Castroviejo, 1993; Gomar, Fernández, Castillo, del Aguila, \& AcuñaCastroviejo, 1993). These data indicate that endogenous opioids indeed may be implicated in anxiety reduction. We have suggested that an anxiolytic action of benzodiazepines and barbiturates is possible only if endogenous opioid systems are activated ( $\AA$ gmo et al., 1995). It must be observed, however, that opiates by themselves are not efficient anxiolytics (McMillan \& Leander, 1975; Pollard \& Howard, 1990).

In an earlier study, we reported that naloxone blocks the anxiolytic-like actions of chlordiazepoxide and diazepam in the light/dark choice procedure and in the free exploratory paradigm in Swiss but not in BALB/c mice (Belzung \& Åmo, 1997). This raises the question of whether the interaction between opioids and benzodiazepines is important in some mouse strains but not in others. It is also possible that the lack of effect of naloxone in the BALB/c mice is specific to the behavioral tests employed. One purpose of the present experiments was to determine whether naloxone could block the anxiolyticlike effects of chlordiazepoxide in the elevated plus-maze. As in the previous study, Swiss and BALB/c mice were used. In addition, another mouse strain, the $\mathrm{C} 57 \mathrm{BL} / 6$, was employed. BALB/c mice show a strong avoidance of the lit area in the light/dark choice procedure and intense neophobia in the free exploratory paradigm, whereas C57BL/6 mice do not. In fact, among several strains, the C57BL/6 mice appear to be the least neophobic or "emotional," and the BALB/c mice the most (Griebel, Belzung, Misslin, \& Vogel, 1993; Misslin, Belzung, \& Vogel, 1989; Peeler \& Nowakowski, 1987; Sudak \& Maas, 1964; Thompson, 1953). The second purpose of this study was, then, to determine whether naloxone is able to block the effects of chlordiazepoxide also in a mouse strain known for its reduced neophobia.

\section{METHOD}

\section{Subjects}

Male Swiss and BALB/c ByJICo mice, 7 weeks of age, were obtained from Janvier (Le Genest Saint Isle, France) and Iffa Credo (l'Arbresle, France), respectively. The C57BL/6 JICo mice were originally obtained from Iffa Credo and then bred in the laboratory for several generations. The subjects were housed 5 per cage under a reversed 12:12-h light:dark cycle (lights on, 2000) at a constant temperature $\left(22^{\circ} \pm 1^{\circ} \mathrm{C}\right)$. Commercial rodent pellets and water were freely available.

\section{Apparatus and Procedure}

The plus-mazes were constructed of polyvinylchloride and elevated to a height of $38.5 \mathrm{~cm}$. The opposing closed arms $(27 \times 5 \mathrm{~cm})$ had $15-\mathrm{cm}$-high walls and were covered by dark paper during tests. The open arms $(27 \times 5 \mathrm{~cm})$ were brightly lit by a $60-\mathrm{W}$ transparent bulb hanging $50 \mathrm{~cm}$ above each arm. Light intensity on the arms' surfaces was about $550 \mathrm{~lx}$. The arms extended from a central platform $(5 \times 5 \mathrm{~cm})$. At the beginning of the test, the mouse was placed on the central platform with its head facing an open arm. The number of entries onto each arm was registered on a hand-held computer (Psion Organiser) during $5 \mathrm{~min}$. The mouse was considered to be on the central platform whenever two paws were posed on it and on any of the arms when the four paws were on it. All the tests were performed between the 6th and the 9th $\mathrm{h}$ of the dark phase of the light:dark cycle. The test room was lit by the lamps installed over the plus-mazes only.

\section{Design}

A parallel groups design was used in such a way that all the doses of a drug or all the combinations of drugs in each particular experiment were run at the same time. Because it was not always possible to run all the animals in a given experiment at a single session, a small number of subjects was given each treatment. The order of drug treatments within each session was randomized. This was then repeated at other sessions until between 8 and 10 mice had received each dose of a drug. Only experimentally naive animals were used.

\section{Drugs}

Naloxone $\mathrm{HCl}$ and chlordiazepoxide $\mathrm{HCl}$ (both from Sigma Chemical, St. Louis) were dissolved in physiological saline and injected i.p. in a volume of $1 \mathrm{ml} / 100 \mathrm{~g}$ of body weight. The interval between drug injection and behavioral observation was $30 \mathrm{~min}$ for chlordiazepoxide and $15 \mathrm{~min}$ for naloxone. Controls were injected with saline vehicle at the corresponding intervals. Naloxone was administered 15 min after chlordiazepoxide, because of the drugs' different kinetics. Brain concentration of the opiate antagonist is maximal already at about $5 \mathrm{~min}$ postinjection, and the half-life is less than $30 \mathrm{~min}$ (Tepperman, Hirst, \& Smith, 1983). It appears that short pretreatment times are essential for naloxone's capacity to block benzodiazepine effects ( $\AA$ gmo et al., 1995). The pretreatment intervals used here are those employed in recent studies of opiate-benzodiazepine interactions (e.g., Ågmo et al., 1995; Belzung \& Ågmo, 1997; Tsuda et al., 1996).

\section{Statistics}

In some of the experiments, the number of open-arms entries was 0 for all saline-treated BALB/c mice. The proportion of entries on the open arms had, therefore, 0 variance in these groups. This excluded the possibility of making parametric tests on the data. In order to make analyses comparable over variables and strains, all the data were evaluated with the nonparametric Kruskal-Wallis analysis of variance. In case of significance, pairwise comparisons were made with the Mann-Whitney $U$ test.

\section{RESULTS}

Chlordiazepoxide increased the proportion of entries on the open arms in all three strains $(H=11.23, p<.05$; $H=5.84, p<.05$, for the Swiss and C57BL/6 strains, respectively; $H=10.56, p<.01$, for the BALB/c strain). Pairwise comparisons between each dose and saline showed that the minimum effective dose was $5 \mathrm{mg} / \mathrm{kg}$ in all the strains (Figure 1).

No significant effect was found on the number of closed-arms entries (Swiss, $H=2.53$, n.s.; BALB/c, $H=$ 2.19 , n.s.; C57BL/6, $H=2.00$, n.s.), although they seemed to increase in the BALB/c mice. Data are shown in Figure 2. 

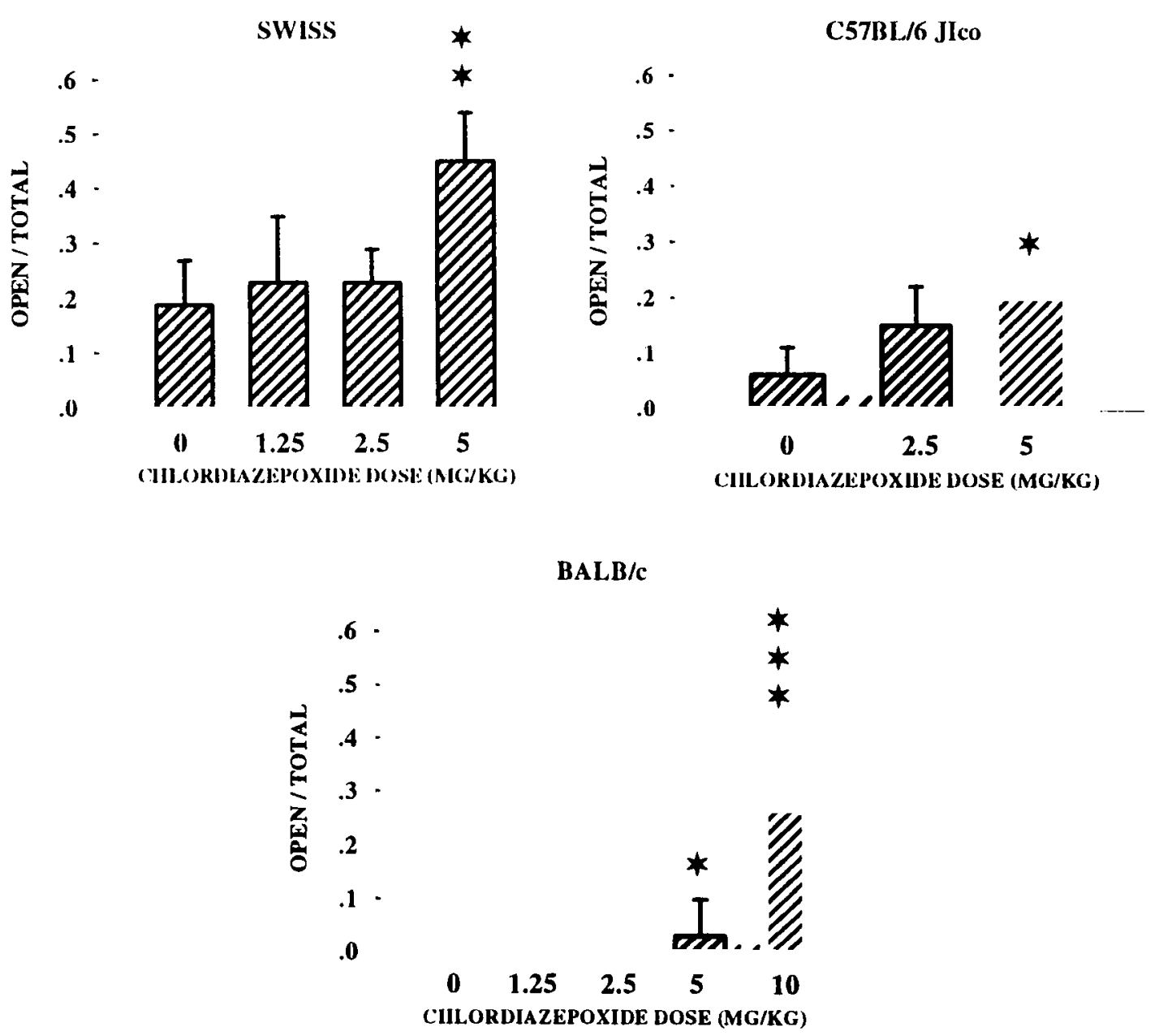

Figure 1. Effects of several doses of chlordiazepoxide on the proportion of open-arms entries in the elevated plusmaze test in Swiss, BALB/c, and C57BL/6 mice. Note that a $10-\mathrm{mg} / \mathrm{kg}$ dose was used only in the BALB/c mice. Because this strain has been reported to have fewer benzodiazepine receptors than the other strains (Robertson, 1979), we expected reduced sensitivity to chlordiazepoxide. The $1.25-\mathrm{mg} / \mathrm{kg}$ dose was skipped in the C57BL/6 strain, because it was far below threshold. Data are medians + semi-interquartile range. ${ }^{\star}$ Different from saline, $p<.05$; ${ }^{\star \star} p<.01 ;{ }^{\star \star \star} p<.001$.

Although it was not the main purpose of the experiment, it may be interesting to compare the plus-maze behavior in the different strains. If the proportion of entries on the open arms after saline treatment is evaluated by the Kruskal-Wallis test, with strain as the independent variable, a significant difference is obtained $(H=18.10, p<$ $.001)$. This is not surprising, because, as was mentioned above, the BALB/c mice did not enter the open arms. Consequently, this strain is different from both the Swiss and the C57BL/6 mice. Furthermore, the Swiss mice showed a larger proportion of entries onto the open arms than the C57BL $/ 6$ mice $(U=87, p<.01)$. The BALB/c strain appears to be less active than the others, because their number of entries on the closed arms was lower than that of the Swiss and C57BL/6 mice, as is shown by the KruksalWallis test $(H=19.53, p<.001)$, followed by the MannWhitney $U$ test (Swiss-BALB/c, $U=98, p<.001$; $\mathrm{C} 57 \mathrm{BL} / 6-\mathrm{BALB} / \mathrm{c}, U=100, p<.001)$. No difference was obtained between the Swiss and the C57BL/6 strains $(U=34$, n.s.). If these same comparisons are made in animals treated with chlordiazepoxide, $5 \mathrm{mg} / \mathrm{kg}$, it is found that some of the strain differences remain. The proportion of entries on the open arms is different between strains $(H=19.29, p<.001)$. Swiss and C57BL/6 mice made a larger proportion of entries on the open arms than did the BALB/c mice (Swiss-BALB/c, $U=98, p<.001$; C57BL/6-BALB/c, $U=85, p<.01)$. The number of entries on the closed arms differed between strains $(H=9.19$, $p<.01$ ), but pairwise comparisons showed that there was no difference between the Swiss and the $\mathrm{BALB} / \mathrm{c}$ mice $(U=62$, n.s. $)$. These latter differed from the $\mathrm{C} 57 \mathrm{BL} / 6$ mice $(U=88, p<.01)$ in that the BALB/c mice made fewer entries.

The effects of naloxone, in doses of 5,10 , and $20 \mathrm{mg} / \mathrm{kg}$, were then evaluated in the Swiss and BALB/c strains. No effect was observed on any parameter (all $p s>.3$ ). This 
SWISS

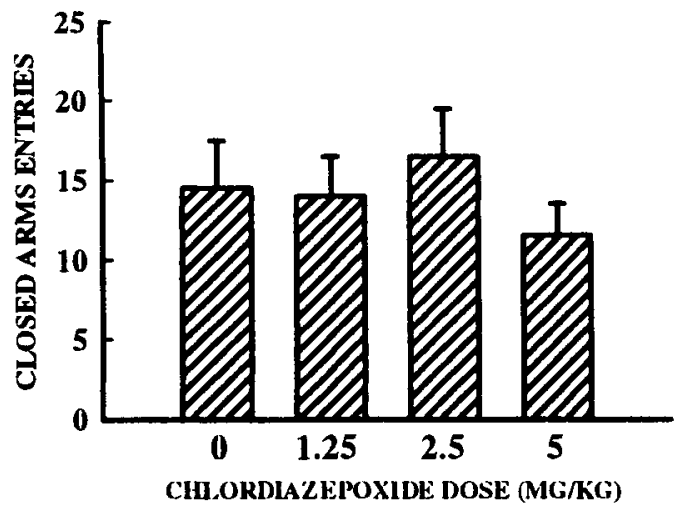

C57BL/6 JIco

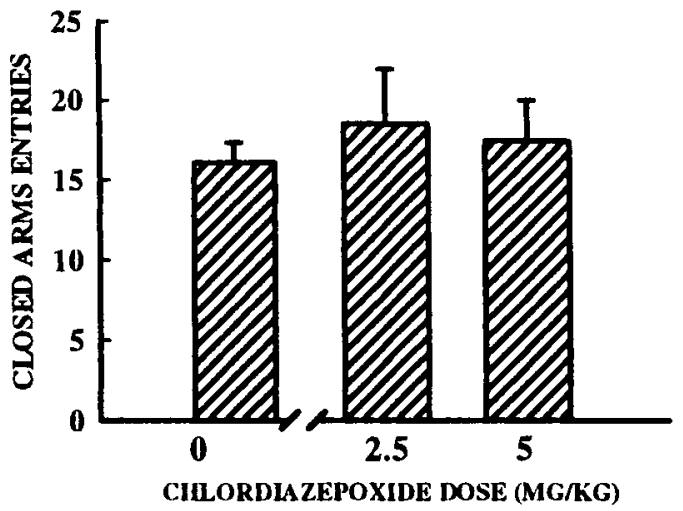

BALB/c

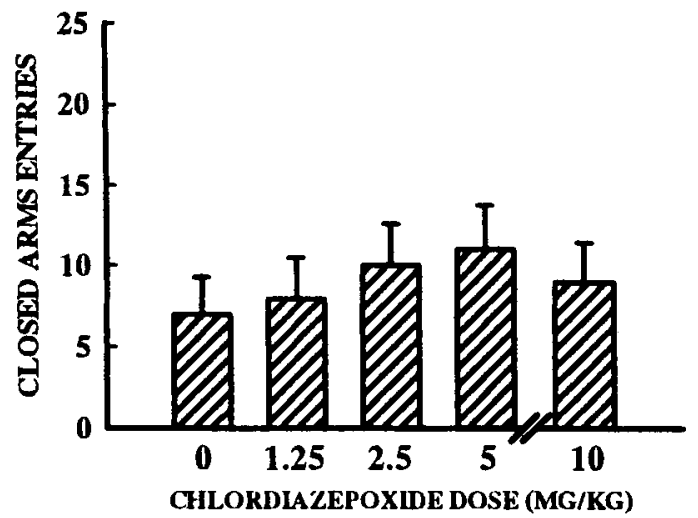

Figure 2. Effects of several doses of chlordiazepoxide on the number of closed-arms entries in the elevated plusmaze test in three mouse strains. Data are medians + semi-interquartile range.

shows that naloxone does not modify anxiety or locomotor activity in the elevated plus-maze. In order to spare animals, the C57BL/6 mice were not included in this experiment. Data for the proportion of open-arms entries are shown in Figure 3.

\section{SWISS}

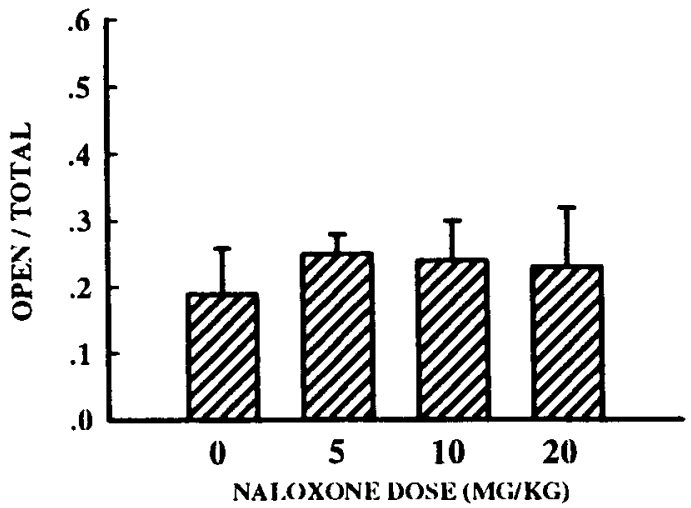

The capacity of naloxone, $10 \mathrm{mg} / \mathrm{kg}$, to block the effects of chlordiazepoxide, $5 \mathrm{mg} / \mathrm{kg}$, was then evaluated in the three mouse strains. In an earlier study in the rat, we reported complete dose-effect curves for the inhibition by naloxone of the anxiolytic effects of benzodi-

Figure 3. Effect of three doses of naloxone on the proportion of open-arms entries in the elevated plus-maze test in Swiss and BALB/c mice. Data are medians + semi-interquartile range. 
SWISS

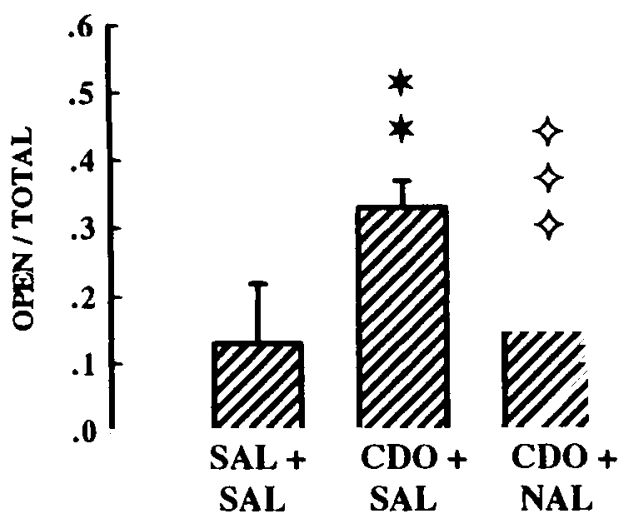

TREATMENT
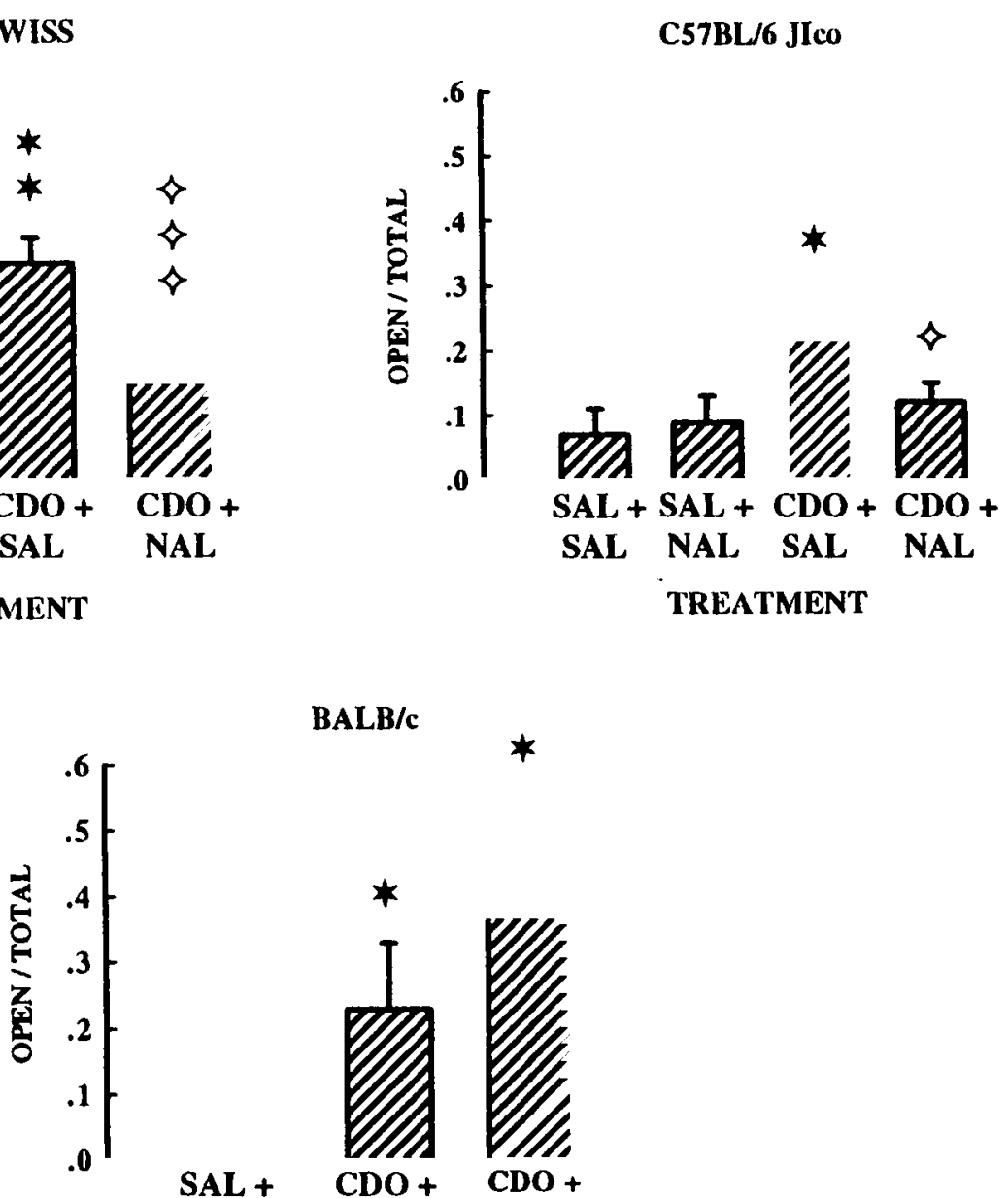

BALB/c

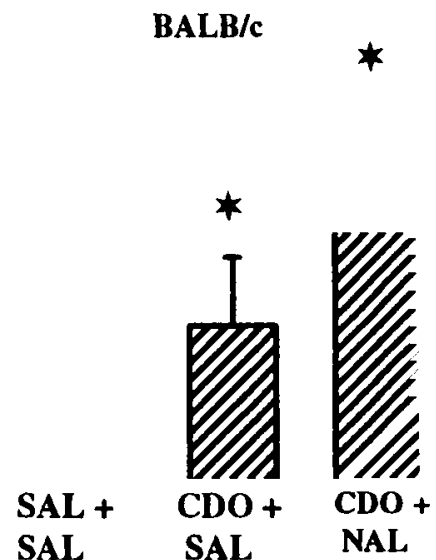

TREATMENT

Figure 4. Inhibition of the anxiolytic-like effect of chlordiazepoxide, $5 \mathrm{mg} / \mathrm{kg}$, on the proportion of open-arms entries by the opiate antagonist naloxone, $10 \mathrm{mg} / \mathrm{kg}$, in three mouse strains. The effect of naloxone alone is also shown in the C57BL/6 strain. Data are medians + semi-interquartile range. SAL, saline; CDO, chlordiazepoxide; NAL, naloxone. ${ }^{\star}$ Different from saline + saline, $p<.05 ;{ }^{* \star} p<.01 ; \diamond$ different from chlordiazepoxide + saline, $p<.05 ; \diamond \diamond \diamond p<.001$.

azepines and pentobarbital ( $\AA$ gmo et al., 1995). A dose of $10 \mathrm{mg} / \mathrm{kg}$ was found to be necessary and sufficient to block the actions of chlordiazepoxide, $5 \mathrm{mg} / \mathrm{kg}$, in the Vogel procedure. It also blocked the actions of diazepam, $2 \mathrm{mg} / \mathrm{kg}$, in the elevated plus-maze ( $\AA \mathrm{gmo}$ et al., 1995). It appeared to be reasonable to use the same dose in the present studies, particularly since the dose-effect curves for chlordiazepoxide are similar in the rat and the mouse. There was a treatment effect on the proportion of openarms entries in all the strains $(H=13.28, p<.001$, and $H=$ $7.40, p<.05$, for the Swiss and C57BL/6 mice, respectively; $H=6.17, p<.05$, for the BALB/c mice). Pairwise comparisons showed that chlordiazepoxide + saline increased this proportion in all the strains. When chlordiazepoxide was combined with naloxone, the increase in the proportion of open-arms entries produced by chlordiazepoxide was completely blocked in the Swiss and
$\mathrm{C} 57 \mathrm{BL} / 6$ strains but not in the BALB/c strain. Data are shown in Figure 4. In the C57BL/6 strain, a group given saline + naloxone, $10 \mathrm{mg} / \mathrm{kg}$, was included. The opiate antagonist alone was ineffective.

There was no effect on the number of closed-arms entries in the Swiss and C57BL/6 strains $(H=5.73$, n.s., and $H=1.51$, n.s., respectively). However, in the BALB/c mice, there was a significant treatment effect on this number $(H=7.37, p<.05)$. Pairwise comparisons showed that mice treated with chlordiazepoxide + saline made more closed-arms entries than animals given saline + saline. Mice treated with chlordiazepoxide + naloxone did not differ from any of the other treatments. The results are summarized in Figure 5.

We again compared the three strains after saline + saline treatment. In this experiment, there was no difference between strains with regard to the proportion of 
SWISS

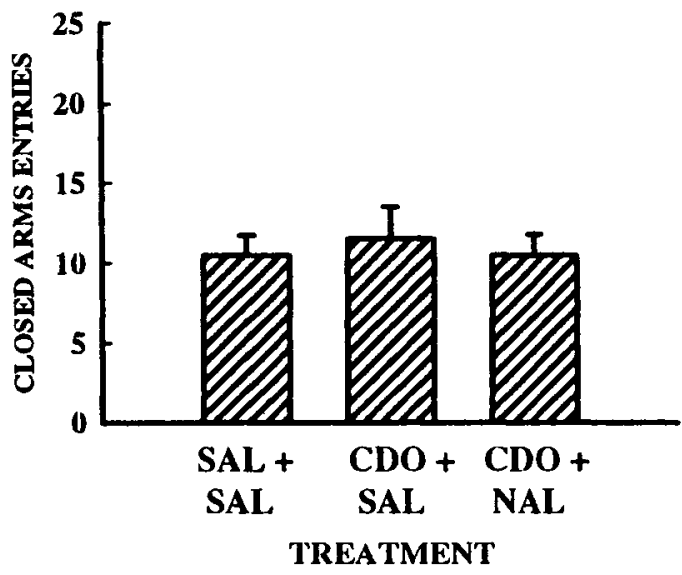

C57BL/6 JIco

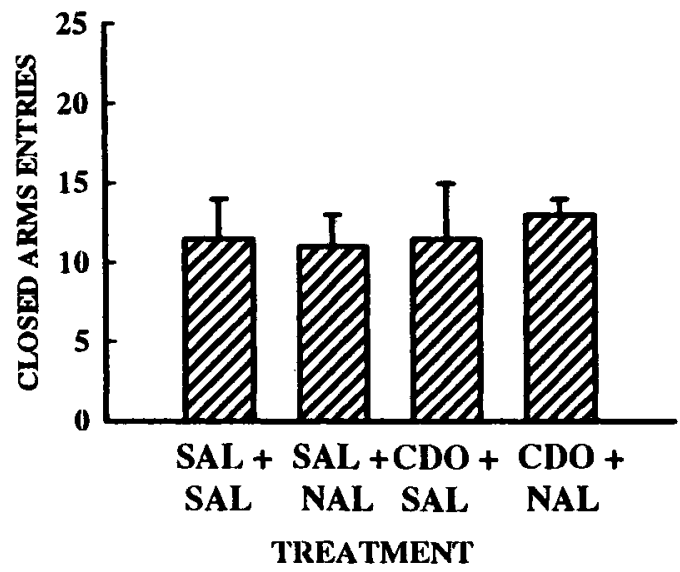

BALB/c

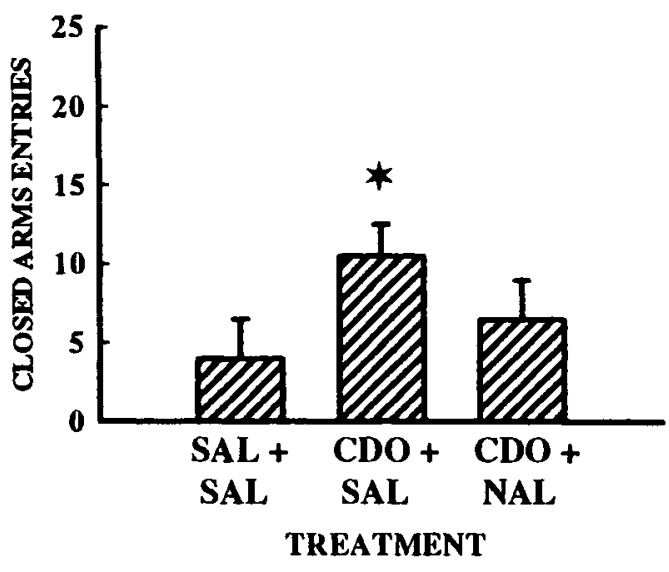

Figure 5. The number of entries on the closed arms in animals treated with chlordiazepoxide, $5 \mathrm{mg} / \mathrm{kg}$, in combination with naloxone, $10 \mathrm{mg} / \mathrm{kg}$. The effect of naloxone alone is also shown in the C57BL/6 strain. Data are medians + semiinterquartile range. SAL, saline; $\mathrm{CDO}$, chlordiazepoxide; $\mathrm{NAL}$, naloxone. *Different from saline + saline, $p<$ .05 .

open-arms entries $(H=1.13$, n.s. $)$. This was due to the fact that 2 of the BALB/c mice entered the open arms in this experiment. One entered once, and the other twice. Because of the low number of closed-arms entries, the proportion of entries on the open arms was large. This was sufficient to abolish statistical significance. The number of closed-arms entries was different $(H=13.94, p<.001)$. The BALB/c mice made fewer entries than the Swiss $(U=97.5, p<.001)$ and the $\mathrm{C} 57 \mathrm{BL} / 6(U=59.5, p<.05)$ mice, whereas the latter two strains made a similar number of entries $(U=22.5$, n.s.). There was no strain difference after treatment with chlordiazepoxide $5 \mathrm{mg} / \mathrm{kg}+$ saline (all $p s>.18$ ). When chlordiazepoxide was combined with naloxone, $10 \mathrm{mg} / \mathrm{kg}$, the proportion of entries on the open arms differed between strains $(H=6.77, p<$ $.05)$. The $\mathrm{BALB} / \mathrm{c}$ mice now displayed a larger proportion of entries than the Swiss $(U=23, p<.05)$ or the C57BL $/ 6$ $(U=12, p<.05)$ mice, whereas there was no difference between these latter $(U=22.5$, n.s. $)$. The number of closedarms entries differed between strains $(H=10.42, p<.01)$. The BALB/c mice made fewer entries than the Swiss $(U=88, p<.01)$ or the C57BL/6 $(U=59.5, p<.05)$ mice. The latter strains made a similar number of entries on the closed arms $(U=43.5$, n.s. $)$.

The ineffectiveness of naloxone in the BALB/c mice in the preceding experiment might have been due to some intrinsic anxiolytic-like activity of the drug in this strain. Although naloxone itself lacked effect in a separate experiment, no group given naloxone + saline was included in the interaction experiment. We therefore decided to replicate the latter with the addition of a group given saline + naloxone. As is shown in Figure 6, the results were almost identical to those obtained in the previous experiment. Again, the treatment effect on the proportion of open-arms entries was significant $(H=20.94, p<$ $.001)$. Pairwise comparisons showed that chlordiazepox- 

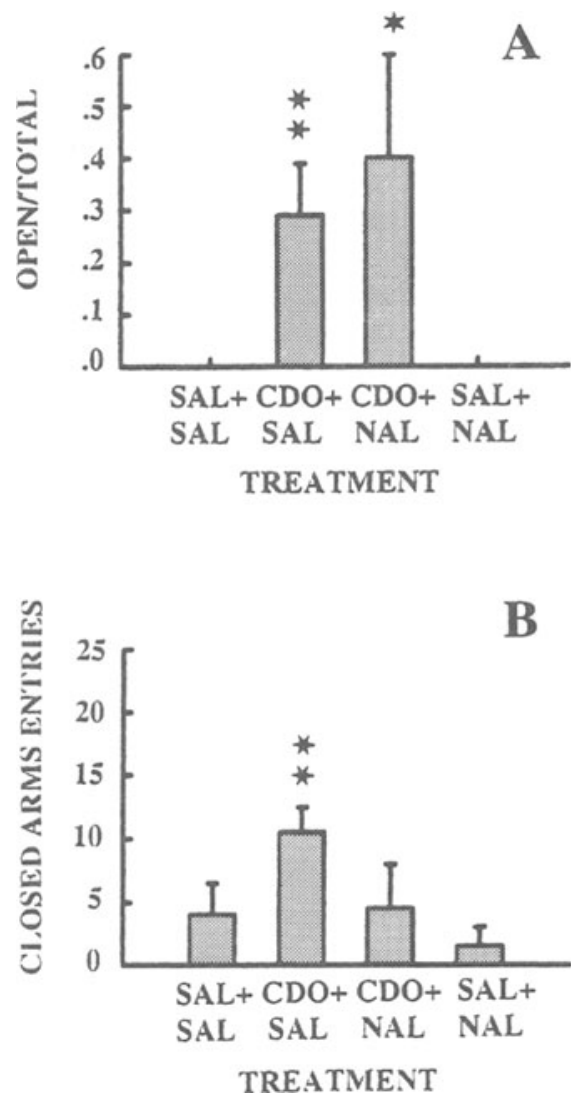

Figure 6. A replication of the experiment in which chlordiazepoxide, $5 \mathrm{mg} / \mathrm{kg}$, was combined with naloxone, $10 \mathrm{mg} / \mathrm{kg}$, with $B A L B / c$ mice. A group given naloxone + saline was also included. Panel $A$, the proportion of entries on the open arms. Panel B, the number of entries on the closed arms. Data are medians + semi-interquartile range. SAL, saline; CDO, chlordiazepoxide; NAL, naloxone. * Different from saline + saline, $p<.05 ;{ }^{\star \star} p<.01$.

ide + saline increased that proportion and that the increase was not affected by naloxone. The antagonist was ineffective by itself. The number of closed-arms entries was also different between groups $(H=15.85, p<.01)$. Chlordiazepoxide + saline augmented the number of entries, whereas no effect was obtained in the other groups. It seemed as if naloxone reduced the increase produced by chlordiazepoxide, inasmuch as the group given chlordiazepoxide + naloxone did not differ from control. However, the difference between the groups given chlordiazepoxide + saline and chlordiazepoxide + naloxone failed to reach significance $(U=75, p=.057)$.

\section{DISCUSSION}

It has repeatedly been reported that the proportion of entries onto the open arms is a sensitive indicator of anxiolytic effects in the elevated plus-maze, whereas the number of entries onto the closed arms and the duration of the visits are sensible to drug effects on locomotor activity (Belzung \& Le Pape, 1994; Cruz, Frei, \& Graeff,
1994; Dawson, Crawford, Collinson, Iversen, \& Tricklebank, 1995; Lister, 1987; Pellow, Chopin, File, \& Briley, 1985). Therefore, effects on durations have not been considered. The number of entries onto the closed arms is systematically used as an indicator of locomotor activity in the present experiments.

The $\mathrm{BALB} / \mathrm{c}$ mice made fewer entries on the open as well as on the closed arms than the other strains in both experiments, whereas the proportion of open-arm entries was lower in one experiment but not in the other. This could suggest that the BALB/c mice are less active but not reliably more "anxious" than the other strains in the plusmaze. However, in procedures specifically designed to measure locomotor activity, there is no difference between $\mathrm{BALB} / \mathrm{c}$ and Swiss or C57BL/6 mice (Belzung, unpublished observations), unless the situation is made stressful (Maas, 1963; Trullas \& Skolnick, 1993). The reduced activity on the plus-maze may, therefore, be a response to stress-induced emotional activation. Exposure to a brightly lit plus-maze is certainly stressful, because plasma corticosteroids are increased as much as they are after exposure to electric footshock (Friedman, Ader, Grota, \& Larson, 1967; Pellow et al., 1985). The fact that chlordiazepoxide increased the number of closed-arms entries in the BALB/c mice in one experiment but never in the other strains supports the notion that reduced activity in the former strain is a consequence of enhanced sensitivity to stress. In fact, when performance on the elevated plus-maze is observed in almost complete darkness (light intensity $<50 \mathrm{~lx}$ ), $\mathrm{BALB} / \mathrm{c}$ mice make a larger proportion of entries on the open arms than do C57BL/6 mice (Trullas \& Skolnick, 1993). Since the aversive element in the plus-maze is exposure to open space (Treit, Menard, \& Royan, 1993), stress should be much reduced in darkness, where the open space would not be perceived. It seems, then, reasonable to maintain that BALB/c mice are more "anxious" in our brightly lit plus-maze and not simply less active than the other strains. Additional evidence for enhanced stress sensitivity in BALB/c mice, unrelated to variations in light intensity, comes from a study in which it was shown that $\mathrm{BALB} / \mathrm{c}$ mice release more dopamine in response to footshock than do C57BL/6 mice (Hervé et al., 1979).

Nevertheless, other data could suggest that BALB/c mice are more sensitive to light than $\mathrm{C} 57 \mathrm{BL} / 6$ mice. It is known that pigmented mice are less photophobic than albino mice (de Fries, Hegman, \& Weir, 1966). Therefore, the pigmented $\mathrm{C} 57 \mathrm{BL} / 6$ should be less light sensitive than the albino BALB/c and Swiss strains. In fact, the C57BL/6 mice made a larger proportion of entries onto the open arms than the BALB/c mice. However, at the same time they displayed a lower proportion of entries than Swiss mice. This latter observation shows that sensitivity to light is not a critical determinant of strain differences on the plus-maze.

Present data show that chlordiazepoxide only affected the parameters presumed to represent anxiolytic effects in the Swiss and C57BL/6 mice. This indicates that our version of the elevated plus-maze is sensitive to anxiolyticlike effects but not to motor effects. Naloxone blocked 
the anxiolytic-like actions of chlordiazepoxide in Swiss and $\mathrm{C} 57 \mathrm{BL} / 6$ mice, whereas no blockade was found in the $B A L B / c$ mice. This observation was replicated in an additional experiment with $\mathrm{BALB} / \mathrm{c}$ mice, in which a group given naloxone + saline was included. Because naloxone alone lacked effect in this as well as in another experiment, it can be excluded that the opiate antagonist possesses some intrinsic anxiolytic-like activity in this strain. There are at least two possible explanations for the inability of naloxone to block the anxiolytic-like effects of chlordiazepoxide in BALB/c mice. First, the baseline difference in anxiety-like behaviors between this strain and C57BL/6 and Swiss mice could be related to differential functioning of opioid systems, in that an "anxious" strain releases smaller amounts of opioids in response to stress than other strains do. Indeed, the BALB/c strain shows a very weak analgesic response to defeat (Miczek \& Thompson, 1984), and swim-stress analgesia is not opioid dependent in this strain (Carmody, Jamieson, \& de Poortere, 1986; Cooper \& Carmody, 1982). Weak or absent defeat or swim-stress-induced analgesia would then be indicative of insignificant opioid release in response to stressful situations. If this is correct and if opioid release were important for anxiolytic actions of benzodiazepines, naloxone should block the actions of chlordiazepoxide in the C57BL/6 and Swiss strains but not in the BALB/c strain, exactly as occurred in the present experiments.

Another possible explanation is that the BALB/c mice have abnormal opioid $\kappa$ receptors and that these receptors are important for the interactions between opioids and benzodiazepines. Interestingly, it has been found that the $\mathrm{BALB} / \mathrm{c}$ strain shows an analgesic response to naloxone and naltrexone (Vaccarino, Tasker, \& Melzack, 1988, 1989), which is not the case in the other mouse strains. This response to naloxone is blocked by a $\kappa$ antagonist (Vaccarino, Plamondon, \& Melzack, 1992). Furthermore, the opioid $\kappa$ agonist U50488H is a potent analgesic in the Swiss and C $57 \mathrm{BL} / 6$ strains but not in the BALB/c strain (Muraki, Oike, Shibata, \& Nomoto, 1991; Takemori, Ho, Naeseth, \& Porthogese, 1988). These data show that there are functional differences between these strains with regard to the $\kappa$ receptor. Interestingly, it has been reported that the anxiolytic-like effects of benzodiazepines in mice are blocked by the $\kappa$ antagonist nor-binaltorphimine ( ̊̊gmo \& Belzung, 1998; Tsuda et al., 1996). It is possible, then, that the strain differences observed here are due to different functioning of the $\kappa$ receptor.

Only one dose of naloxone was used in the present experiments. This dose was determined from earlier data in the rat, where full dose-effect curves for naloxone's inhibition of benzodiazepine and barbiturate anxiolyticlike effects were obtained ( $\AA$ gmo et al., 1995). The dose used here was the minimum dose that completely blocked the effects of chlordiazepoxide, $5 \mathrm{mg} / \mathrm{kg}$. It could be argued that a larger dose also might have blocked the effects of this benzodiazepine in the $\mathrm{BALB} / \mathrm{c}$ mice. This seems unlikely, however, because BALB/c and Swiss mice are equally sensitive to naloxone's blockade of morphine- induced hyperthermia (Belzung \& Ågmo, 1997). This observation suggests that there are no functionally important strain differences in pharmacodynamics or pharmacokinetics of naloxone between Swiss and BALB/c mice.

The inability of naloxone to block the anxiolytic-like effects of chlordiazepoxide in $\mathrm{BALB} / \mathrm{c}$ mice has now been confirmed in three different procedures. This shows that it is not a procedure-specific phenomenon. On the other hand, naloxone efficiently blocks these effects in Swiss mice in the same procedures. Present data show that the C57BL/6 strain also is sensitive to naloxone-antagonism in the elevated plus-maze. Interestingly, the three strains are equally sensitive to the anxiolytic-like actions of chlordiazepoxide, as is shown by the similar dose-effect curves. This implies that there is no correlation between the sensitivity to the effects of chlordiazepoxide and naloxone's ability to antagonize these effects. In this context, it has been observed that BALB/c mice have a lower density of central benzodiazepine receptors than $\mathrm{C} 57 \mathrm{BL} / 6$ mice (Robertson, 1979). There is no difference in affinity, however. The reduced receptor density $\left(B_{\max }\right)$ may be related to baseline "anxiety" level, but does not seem to affect the response to chlordiazepoxide. Obviously, more studies are needed before it is possible to understand the mechanisms responsible for opioid antagonists' ability to block anxiolysis and to explain the strain differences observed.

\section{REFERENCES}

Ågmo, A., \& BeLzUNG, C. (1998). The role of subtypes of the opioid receptor in the anxiolytic action of chlordiazepoxide. Neuropharmacology, 37, 223-232.

Ågmo, A., \& FernándeZ, H. (1991). Benzodiazepine receptor ligands and sexual behavior in the male rat: The role of GABAergic mechanisms. Pharmacology, Biochemistry \& Behavior, 38, 781-788.

Ågmo, A., Galván, A., Heredia, A., \& Morales, M. (1995). Naloxone blocks the antianxiety but not the motor effects of benzodiazepines and pentobarbital: Experimental studies and literature review. Psychopharmacology, 120, 186-194.

Ågmo, A., Pruneda, R., Guzmán, M., \& Gutiérrez, M. (1991) GABAergic drugs and conflict behavior in the rat: Lack of similarities with the actions of benzodiazepines. Naunyn-Schmiedeberg's Archives of Pharmacology, 344, 314-322.

Ågmo, A., \& TARASCO, C. (1985). Interactions between naloxone and GABA in the control of locomotor activity in the rat. Journal of Neural Transmission, 61, 137-149.

BelzUNG, C., \& ÅGmo, A. (1997). Naloxone blocks anxiolytic-like effects of benzodiazepines in Swiss but not in Balb/c mice. Psychopharmacology, 132, 195-201.

Belzung, C., \& Le PaPe, G. (1994). Comparison of different behavioral test situations used in psychopharmacology for measurement of anxiety. Physiology \& Behavior, 56, 623-628.

Billingsley, M. L., \& Kubena, R. K. (1978). The effects of naloxone and picrotoxin on the sedative and anticonflict effects of benzodiazepines. Life Sciences, 22, 897-906.

Boone, J. B., JR., \& MCMillen, D. (1994). Differential effects of prolonged restraint stress on proenkephalin gene expression in the brainstem. Molecular Brain Research, 27, 290-298.

Brady, K. T., Lydiard, R. B., Ballenger, J. C., Shook, J., Laraia, M., \& FoSSEY, M. (1991). CSF opioids in panic disorder. Biological Psychiatry, 30, 512-514.

Carmody, J., Jamieson, D., \& de Poortere, R. (1986). Opioidindependent hyperalgesia induced in mice by pentobarbitone at low dosage. Naunyn-Schmiedeberg's Archives of Pharmacology, 334, 193-195. 
CoOper, K. A., \& CARmody, J. J. (1982). The characteristics of the opioid-related analgesia induced by the stress of swimming in mice. Neumscience Letters, 31, 165-170.

Cruz, A. P. M., Frei, F., \& GraefF, F. G. (1994). Ethopharmacological analysis of rat behavior on the elevated plus-maze. Pharmacology, Biochemistry \& Behavior, 49, 171-176.

Dawson, G. R., Crawford, S. P., Collinson, N., Iversen, S. D., \& TRICKLEBANK, M.D. (1995). Evidence that the anxiolytic-like effects of chlordiazepoxide on the elevated plus maze are confounded by increases in locomotor activity. Psychopharmacology, 118, 316-323.

de Fries, J. C., Hegman, J. P., \& Weir, M. W. (1966). Open-field behavior in mice: Evidence for a major gene effect mediated by the visual system. Science, 154, 1577-1579.

Dienstbier, R. A., Crabbe, J., Johnson, G. O., Thorland, W., Jorgensen, J. A., SAdar, M. M., \& La Velle, D. C. (1981). Exercise and stress tolerance. In M. H. Sacks \& M. L. Sachs (Eds.), Psychology of running (pp. 193-210). Champaign, IL: Human Kinetics Publishers.

Dingledine, R., IVERSEN, L. L., \& Breuker, E. (1978). Naloxone as a GABA antagonist: Evidence from iontophoretic, receptor binding and convulsant studies. European Journal of Pharmacology, 47, 19-27.

Duka, T., Cumin, R., Haefely, W., \& Herz, A. (1981). Naloxone blocks the effect of diazepam and meprobamate on conflict behaviour in rats. Pharmacology, Biochemistry \& Behavior, 15, 115-117.

DUKA, T., WüsTER, M., \& HERZ, A. (1979). Rapid changes in enkephalin levels in rat striatum and hypothalamus induced by diazepam. NaunynSchmiedeberg's Archives of Pharmacology, 309, 1-5.

Duka, T., WüsTER, M., \& HeRz, A. (1980). Benzodiazepines modulate striatal enkephalin levels via a GABAergic mechanism. Life Sciences, 26, 771-776.

FILE, S. E. (1982). Chlordiazepoxide-induced ataxia, muscle relaxation and sedation in the rat: Effects of muscimol, picrotoxin and naloxone. Pharmacology, Biochemistry \& Behavior, 17, 1165-1170.

Friedman, S. B., Ader, R., Grota, L. J., \& Larson, T. (1967). Plasma corticosterone response to parameters of electric shock in the rat. Psychosomatic Medicine, 29, 323-328.

Gomar, M. D., Castillo, J. L., del Aguila, C. M., Fernández, B., \& ACUÑA-CASTROVIEJO, D. (1993). Intracerebroventricular injection of naloxone blocks melatonin-dependent brain $\left[{ }^{3} \mathrm{H}\right]$-flunitrazepam binding. NeuroReport, 4, 987-990.

Gomar, M. D., Fernández, B., Castillo, J. L., del Aguila, C. M., \& ACUÑA-CASTROVIEJO, D. (1993). Suppressive effect of simultaneous injection of $\mathrm{ACTH}_{1-10}$ and $\boldsymbol{\beta}$-endorphin on brain $\left[{ }^{3} \mathrm{H}\right]$ flunitrazepam binding. NeuroReport, 5, 252-254.

Griebel, G., Belzung, C., Misslin, R., \& Vogel, E. (1993). The freeexploratory paradigm: An effective method for measuring neophobic behavior in mice and testing potential neophobia-reducing drugs. Behavioral Pharmacology, 4, 637-644.

Harsing, L. G., Yang, H. Y., \& Costa, E. (1982). Evidence for $\gamma$ aminobutyric acid (GABA) mediation in the benzodiazepine inhibition of met $^{5}$-enkephalin elicited by depolarization. Journal of Pharmacology \& Experimental Therapeutics, 220, 616-620.

HENNIG, J., LASCHEFSKI, U., \& OPPER, C. (1994). Biopsychological changes after bungee-jumping: $\beta$-endorphin immunoreactivity as a mediator of euphoria? Neuropsychobiology, 29, 28-32.

Hervé, D., Tassin, J. P., Barthelemy, C., Blanc, G., Lavielle, S., \& GLOWINSKI, J. (1979). Difference in the reactivity of the mesocortical dopaminergic neurons to stress in the $\mathrm{BALB} / \mathrm{C}$ and $\mathrm{C} \% / \mathrm{BL} / 6$ mice. Life Sciences, 25, 1659-1664.

KоOB, G. F., STRECKER, R. E., \& BloOM, F. E. (1980). Effects of naloxone on the anticonflict properties of alcohol and chlordiazepoxide. Substance \& Alcohol Actions/Misuse, 1, 447-457.

LARSEN, P. J., \& MAU, S. E. (1994). Effect of acute stress on the expression of hypothalamic messenger ribonucleic acids encoding the endogenous opioid precursors preproenkephalin A and proopiomelanocortin. Peptides, 15, 783-790.

LISTER, R. G. (1987). The use of a plus-maze to measure anxiety in the mouse. Psychopharmacology, 92, 180-185.

MAAS, J. W. (1963). Neurochemical differences between two strains of mice. Nature, 197, 255-257:
Mcmillan, D. E., \& Leander, J. D. (1975). Drugs and punished responding: V. Effects of drugs on responding suppressed by responsedependent and response-independent electric shock. Archives Internationales de Pharmacologie, 213, 22-27.

MiczeK, K. A., \& Thompson, M. L. (1984). Analgesia resulting from defeat in a social confrontation: The role of endogenous opioids in the brain. In R. Bandler (Ed.), Modulation of sensorimotor activity during alterations in behavioral states (pp. 431-456). New York: Liss.

Misslin, R., Belzung, C., \& Vogel, E. (1989). Behavioural validation of a light/dark choice procedure for testing anti-anxiety agents. $B e$ havioral Processes, 18, 119-132.

Muraki, T., Oike, N., Shibata, Y., \& Nomoto, T. (1991). Analgesic effect of $\mu$ - and $\kappa$-opioid agonists in beige and CXBK mice. Journal of Pharmacy \& Pharmacology, 43, 210-212.

PeEler, D. F., \& Nowakowski, R. S. (1987). Genetic factors and the measurement of exploratory activity. Behavioral \& Neural Biology, 48, $90-103$

Pellow, S., Chopin, P., File, S. E., \& Briley, M. (1985). Validation of open:closed arm entries in an elevated plus maze as a measure of anxiety in the rat. Journal of Neuroscience Methods, 14, 149-167.

Pollard, G. T., \& Howard, J. L. (1990). Effects of drugs on punished behavior: Pre-clinical tests for anxiolytics. Pharmacology \& Therapeutics, $45,401-424$.

RoBertson, H. A. (1979). Benzodiazepine receptors in "emotional" and "non-emotional" mice: Comparison of four strains. European Journal of Pharmacology, 56, 163-166.

Schedlowski, M., Flüge, T., Richter, S., Tewes, U., Schmidt, R. E., \& WAGNER, T. O. F. (1995). $\beta$-endorphin, but not substance P, is increased by acute stress in humans. Psychoneuroendocrinology, 20, $103-110$

SOUBriÉ, P., Jobert, A., \& ThIEBot, M. H. (1980). Differential effects of naloxone against the diazepam-induced release of behavior in rats in three aversive situations. Psychopharmacology, 69, 101-105.

SUDAK, H. S., \& MAAS, J. W. (1964). Central nervous system serotonin and norepinephrine localization in emotional and non-emotional strains of mice. Nature, 203, 1254-1256.

Takemori, A. E., Ho, B. Y., Naeseth, J. S., \& Porthogese, P. S (1988). Nor-binaltorphimine, a highly selective kappa-opioid antagonist in analgesic and receptor binding assays. Journal of Pharmacology \& Experimental Therapeutics, 246, 255-258.

Tepperman, F. S., Hirst, M., \& Smith, P. (1983). Brain and serum levels of naloxone following peripheral administration. Life Sciences, 33, 1091-1096

THompson, W. R. (1953). The inheritance of behavior: Behavioral differences in fifteen mouse strains. Canadian Journal of Psychology, 7, 145-155.

Treit, D., Menard, J., \& Royan, C. (1993). Anxiogenic stimuli in the elevated plus-maze. Pharmacology, Biochemistry \& Behavior, 44, 463-469.

Trullas, R., \& Skolnick, P. (1993). Differences in fear motivated behaviors among inbred mouse strains. Psychopharmacology, 111 323-331.

Tsuda, M., Suzuki, T., Misawa, M., \& Nagase, H. (1996). Involvement of the opioid system in the anxiolytic effect of diazepam in mice. European Journal of Pharmacology, 307, 7-14

Vaccarino, A. L., Plamondon, H., \& Melzack, R. (1992). Analgesic and aversive effects of naloxone in BALB/c mice. Experimental Neurology, 117, 216-218.

Vaccarino, A. L., Tasker, R. A. R., \& Melzack, R. (1988). Systemic administration of naloxone produces analgesia in BALB/c mice. Neuroscience Letters, 84, 103-107.

Vaccarino, A. L., Tasker, R. A. R., \& Melzack, R. (1989). Analgesia produced by normal doses of opiate antagonists alone or in combination with morphine. Pain, 36, 103-109.

Wüster, M., DuKa, T., \& HERZ, A. (1980). Diazepam effects on striatal met-enkephalin levels following long-term pharmacological manipulations. Neuropharmacology, 19, 501-505.

(Manuscript received March 25, 1997; revision accepted for publication October 1, 1998.) 